\title{
Crafting Measures To Expand Trade And Cooperation Between South Korea And Mongolia
}

\author{
Jon-Mo Yoon ${ }^{1}$ \\ ${ }^{1}$ Professor, Liberal Arts College, Dankook University, Korea, Jyoon2010@naver.com
}

\begin{abstract}
Mongolia, which is a globally resource-rich country with its copper and coal deposits ranked fifth in the world, has been maintaining an amicable relationship with South Korea since the two countries first established diplomatic ties in 1990. As the Korean government has recently promoted the New Northbound Policy, there is a growing importance of expanding multilateral collaboration with Mongolia from the aspects of geopolitical advantage, strategy, and economic trade. Mongolia demonstrated a high economic growth rate until recently as an emerging economy of Asia and is making efforts to establish an insufficient manufacturing base and build logistics and key infrastructure using its economic growth output. South Korea imports raw materials from Mongolia, such as minerals, and exports petrochemical products and automobiles to Mongolia. The two countries agreed to sign an economic treaty of economic partnership agreement (EPA) in the future. While Mongolia has increasing economic value as a supply and export base and strategic value owing to its geopolitical location, the collaboration level and trade volume between South Korea and Mongolia remain at a low level. Therefore, this paper examines Mongolia's main industries and relevant trends, together with the country's policy issues. This paper suggests diverse plans that can expand trade and cooperation between two countries and increase the synergic effect of market share occupancy by South Korean companies when they enter the Mongolian market. Various measures are presented through SWOT analysis, trend analysis and trade data from South Korean and Mongolian perspectives. From the South Korean perspective, measures are presented for investment and major entry fields, and from the Mongolian perspective, economic environment improvement, such as market opening, is mentioned. In addition, the rapid promotion of the EPA between the two countries is presented.
\end{abstract}

Keywords: Mongolia, South Korea,Trade, Measures, EPA

\section{Introduction}

Mongolia is located in a landlocked plateau in the northern region of Central Asia, surrounded by meadows and forests, and the nation's land area is more than seven times that of the Korean Peninsula, which combines South and North Korea. Mongolia has a small population of approximately 3.3 million. The capital is Ulaanbaatar, and the country has a climate of dry air and severe temperature difference, as it is affected by the nearby Gobi Desert. Its neighboring countries include China in the South and Russia in the North. As a newly emerging economy, Mongolia is in an early stage of development and does not possess enough economic power to pursue economic prosperity. Mongolia established a communist government in 1924, with support from the Soviet Union.

After the collapse of the Soviet Union, Mongolia became a semi presidential representative democratic republic in 1992, where the president is directly elected and the parliamentary cabinet plays the key role. The economic system also converted from a planned economy to market economy.

Received: June 18, 2021; $1^{\text {st }}$ Review Result: August 02, 2021; $2^{\text {nd }}$ Review Result: September 20, 2021 Accepted: October 31, 2021 
A recent constitutional reform changed the two-term presidential system to a single-term presidential system. Mongolia is one of the top ten producers of mineral resources globally, possessing approximately 80 types of minerals. As a result, the mining industry and related industries contribute to most of the national economy and industry. In particular, the mining industry occupies nearly onefourth of the total gross domestic product (GDP), which has a large influence on the entire industrial circle. However, Mongolian economy is sensitive to and largely affected by the global market price of raw materials. It has a high economic dependence on China, and the trade volume between the two countries accounts for more than $80 \%$ of the total trade in Mongolia. For decreasing its biased economic dependence on China, Mongolia has recently begun reinforcing collaboration and signing new economic treaties with other foreign countries, particularly Japan and India. South Korea established diplomatic relations with Mongolia in 1990 and initiated investment in the country in 1994. The two countries recently agreed to sign an economic partnership agreement (EPA) in the foreseeable future. As the Korean government is currently promoting the New Northbound Policy, Mongolia has a growing importance toward South Korea in terms of geopolitical advantage, mutual benefit from trade, and potential as a future supply base of raw materials and export base. However, the collaboration level and trade volume between the countries remain at a low level, and it is necessary to find ways to improve and expand it. This topic has rarely been studied, and most studies on Mongolia are related to humanities, such as studies on Mongolian history and culture or linguistic similarities.

Among a few studies that have examined the collaboration and trade relations between South Korea and Mongolia, Odmaa[1] researched the trade structures of Mongolia, Korea, and China and indicated that Mongolian trade is biased toward China and is recording trade deficit with Korea. The study suggested the necessity of concluding an economic treaty considering the low level of collaboration between the two countries at present. By examining the trade structure and economic collaboration between South Korea and Mongolia, Han[2] proposed expanding the trade volume and foreign domestic investment (FDI) between the two countries and forming a separate economic collaboration committee that can accelerate material and human exchange for economic cooperation. Park[3] examined the plans of Korean logistics companies for entering Mongolian markets and asserted the necessity of building logistics infrastructure in Mongolia and implementing efficient logistics policies by the governments of both countries. Park[4] examined the dependency of the Mongolian economy and economic collaboration with the Korean economy and emphasized mutual collaboration, rather than simple exploitation of resources, in the development of the processing industry, export route, and green energy industry. The abovementioned studies also focused on Mongolia in fragmentary terms, mainly on economy, trade, and cooperation, but very few papers have analyzed the current situation as a whole. Meanwhile, President Ukhnaagiin Khürelsükh, who was elected in the presidential election held in June 2021, advocated the presidential election promise of national reconciliation and national development[5]. He attempted to establish a new by securing the diversity of the domestic industrial structure's economic structure through a strengthened collaboration with global economic leading countries and establishment of domestic infrastructure. He also tried to fairly distribute the economic wealth obtained from the exploitation of mineral resources and further develop it. Mongolia is currently working on a project of revitalizing trade and developing the mining industry and agricultural processed product businesses by expanding economic cooperation with and investment invitation from major economies, including Korea, and turning the nation into a transportation and service hub by replenishing domestic infrastructure, such as transportation, logistics, and energy facilities. This Mongolian environment is considered a good opportunity to break away from the economic structure that relied on China and expand trade between South Korea and Mongolia, which was relatively inactive compared to the long period of exchange, as suggested in the previous reference paper. In addition, this environment can play a critical role in the early conclusion of an EPA 
between the two countries. Thus, this study closely examines the main industries, trends, and relevant issues of Mongolia that not only adhere to the Korean government's new policy paradigm but also have high complementariness in terms of the value and economic perspectives as a future supply base of raw materials and export base. Based on an analysis of the ways to promote South Korean companies' entry into the Mongolian market and expand trade and cooperation between the two countries, this paper proposes relevant plans.

\section{Multiple Trends in Mongolia}

\subsection{Trade and Economy of Mongolia}

Minerals contribute towards most of Mongolian exports. However, considerable expenses are incurred due to the insufficient infrastructure for transportation and electricity. The mineral production and development in Mongolia is mostly processed by investment from foreign countries, and the country makes huge payments to foreign investors in the forms of interests and dividend. Due to these expenses, Mongolia is in a constant state of current account deficit, which refers to a country's imports and exports of goods and services in trade with foreign countries. In contrast, according to [Table 1], referred from the data of UN Comtrade and IMF, Mongolia has been consistently recording trade surplus since 2014. In 2018 and 2019, Mongolian trade reached approximately 13 billion USD, with a promising outlook in the next year[6]. However, the volume unexpectedly decreased in 2020, which can be attributed to the global economic slowdown triggered by COVID-19; shrunken demand for minerals by China, which is the largest trading country in Mongolia; decreased foreign investment; and sustained border closure. Moreover, Mongolian imports decreased considerably in 2020 compared to the same period a year ago. Many economic organizations have forecasted that the country will recover a high economic growth rate in 2021 at approximately 5\%. The contracted economy is expected to recover to a certain level, considering the rapid recovery of the Chinese economy, the increase in global demand for minerals, and the Mongolian government's fiscal expansion and tax reduction policies.

[Table 1] Volume of Export and Import

\begin{tabular}{|c|c|c|c|}
\hline Year & Export (Billion \$) & Import (Billion \$) & Trade balance (Billion \$) \\
\hline 2020 & 7.03 & 5.40 & 1.63 \\
\hline 2019 & 7.61 & 6.13 & 1.48 \\
\hline 2018 & 7.01 & 5.87 & 1.14 \\
\hline 2017 & 6.20 & 4.34 & 1.86 \\
\hline 2016 & 4.91 & 3.35 & 1.56 \\
\hline
\end{tabular}

The nation recorded a GDP of 11 billion USD in 2016, which increased by $18 \%$ to 13 billion USD in 2019. The per capita GDP of Mongolia was low, similar to other emerging economies, and has remained at approximately 4,000 USD since 2018-according to [Table 2], referred from the UN Comtrade and IMF. In 2020, the per capita GDP dropped by $22 \%$ from the previous year to approximately 3,000 USD due to the COVID-19 pandemic. The inflation rate was as high as $8.5 \%$ in 2019 and decreased to $3.7 \%$ in 2020 . Fiscal balance, which refers to the government's earnings and expenses, reached its peak in 2016 due to the risk of sovereign default. Since then, the fiscal balance has gradually recovered to a record surplus in 2018 and 2019, but the nation recorded another large fiscal deficit in 2020. Mongolia recorded a high economic growth rate of over $10 \%$ until the early 2010s. Since 2014, however, the rate has declined because of the lower global mineral price, shrunken investment of foreign countries, and slower economic growth of China's largest trading partner. Mongolia received a bailout from the IMF in 2017 due to the sovereign default risk, and accordingly, achieved economic growth of over 5\%[7]. In 2020, the economic growth rate fell under zero due to the 
pandemic. Global economic organizations have forecasted that the Mongolian economic growth rate will turn positive to reach over $5 \%$, as in other years, considering the rapid recovery of the Chinese economy and subsequent increase in mineral exports as well as the price increase of Mongolia's main mineral resources, such as copper and gold.

[Table 2] Foreign Economic Indicators

\begin{tabular}{|c|c|c|c|c|c|}
\hline Year & 2016 & 2017 & 2018 & 2019 & 2020 \\
\hline GDP (billion \$) & 11.2 & 11.1 & 13.0 & 13.2 & 13.8 \\
\hline Economic growth rate (\%) & 1.20 & 5.30 & 6.9 & 5.1 & -5.3 \\
\hline Per capita GDP (\$) & 3,120 & 3,780 & 4,104 & 4,295 & 3,354 \\
\hline Inflation rate (\%) & 0.7 & 4.3 & 6.8 & 8.5 & 3.7 \\
\hline Financial balance / GDP & -15.3 & -3.8 & 3.0 & 0.8 & -9.7 \\
\hline
\end{tabular}

* Forecasts 2020

Transparency International (TI), located in Berlin, Germany, has published the Corruption Perceptions Index (CPI) every year since 1995[8]. CPI, which measures the integrity of a country, ranks 180 countries according to their perceived levels of public sector corruption based on 13 items and a survey conducted by ten organizations. Over the past five years, Mongolia's CPI has been in the late 30s. As of 2020, Mongolia has ranked 111th out of the 180 countries. After reaching 87th place in 2016, Mongolia started going down in rank. A high CPI means a high chance of experiencing unreasonableness and discrimination in the economy and society. It also means that social connections and personal networks are required when solving problems of approval or authorization once they occur. In Mongolia, power abuse by politicians and public officials frequently occurs, while the judicial branch holds little power. The transparency of government expenses is also low. These can become concerning issues for foreign companies when investing in Mongolia. Mongolia has recently reinforced supervision and prepared for solutions and relevant policies. However, the improvement is still slow without visible achievement, and the national ranking is in a downward trend.

It took an average of $302 \mathrm{~h}$ and a cost of 289 USD for exports of Mongolia in 2020-according to [Table 3], referred from data of World Bank. The average time and cost in the case of the East Asia and Pacific regions were $114 \mathrm{~h}$ and 490 USD, respectively. In contrast, Korea required an average of $14 \mathrm{~h}$ and a cost of $196 \mathrm{USD}$ for exports. There was a significant difference in cost expenses between South Korea and Mongolia, and the time differed almost 20 times. In the case of time and cost for imports, Mongolian imports incurred an average time of $179 \mathrm{~h}$ and a cost of 293 USD. These values were $122 \mathrm{~h}$ and $531 \mathrm{USD}$, respectively, in the case of the East Asia and Pacific region, and $7 \mathrm{~h}$ and 342 USD for South Korea[9]. While Mongolia required ten times more hours than South Korea, it had fewer expenses. This result can be attributed to the differences in economic volume, infrastructure, and technology of the customs clearance system between the two countries. Thus, the system needs to be improved so that the customs clearance process in Mongolia can be effectively monitored and managed in the future.

[Table 3] Trading across Borders

\begin{tabular}{|c|c|c|c|}
\hline Divison & Mongolia & East Asia \& Pacific & South Korea \\
\hline Time to export: Border compliance (hr) & 134 & 58 & 13 \\
\hline Cost to export: Border compliance (\$) & 225 & 381 & 185 \\
\hline Time to export: Documentary compliance (hr) & 168 & 56 & 1 \\
\hline Cost to export: Documentary compliance (\$) & 64 & 109 & 6 \\
\hline Time to import: Border compliance (hr) & 48 & 68 & 315 \\
\hline Cost to import: Border compliance (\$) & 210 & 423 & 1 \\
\hline Time to import: Documentary compliance (hr) & 115 & 54 & 27 \\
\hline Cost to import: Documentary compliance $(\$)$ & 83 & 108 & 6 \\
\hline
\end{tabular}


According to [Table 4], referred from the data of UN Comtrade and world integrated trade solution (WITS), mineral resources occupy the largest proportion of both export and imports items in Mongolia. As of 2019, mineral resources, such as mineral oil, bitumen, and ore, occupied more than $80 \%$ of the exports and non-metals, including pearl and relevant items, have occupied $6 \%$ of the exports. Textile fiber products, including wool, occupied 5\%, followed by salt and lime, which occupied $3 \%$, and meat, which has occupied $1 \%$. Similar to the export items, mineral resources, such as mineral oil, bitumen, and ore, have occupied the largest proportion of the total imports (22\%). Railway, automobile, and related components, which are Korea's main exported items to Mongolia, have a 16\% share of the total imports. Machine and components, including nuclear reactors and steel products, occupied $14 \%$ and $8 \%$, respectively. The proportions of electric machines and related components and aircraft-related components were $6 \%$ and slightly under $3 \%$, respectively. As for the regulation and tariffs on Mongolian imports, the country is imposing high duties, from a minimum of $20 \%$ to a maximum of $40 \%$, on agricultural products, liquor, meat, and vegetables imported from foreign countries for developing domestic industries[10].

[Table 4] Main Export and Import Items

\begin{tabular}{|c|c|c|c|c|c|}
\hline \multirow[b]{2}{*}{ Division } & \multicolumn{2}{|c|}{ Export structure } & \multirow[b]{2}{*}{ Division } & \multicolumn{2}{|c|}{ Import structure } \\
\hline & $\begin{array}{c}\text { Volume } \\
\text { (Billion \$) }\end{array}$ & $\begin{array}{l}\text { Share } \\
(\%)\end{array}$ & & $\begin{array}{l}\text { Volume } \\
(\text { Billion \$) }\end{array}$ & $\begin{array}{c}\text { Share } \\
(\%)\end{array}$ \\
\hline Mineral fuels, mineral oils & 3.48 & 46 & $\begin{array}{l}\text { Mineral fuels, mineral oils and } \\
\text { products of their distillation; } \\
\text { bituminous substances }\end{array}$ & 1.35 & 22 \\
\hline Ores, slag and ash & 2.68 & 35 & $\begin{array}{l}\text { Vehicles other than railway or } \\
\text { tramway rolling stock, and parts } \\
\text { and accessories }\end{array}$ & 0.99 & 16 \\
\hline $\begin{array}{l}\text { Natural or cultured pearls, } \\
\text { precious or semi-precious } \\
\text { stones, precious metals }\end{array}$ & 0.42 & 5.5 & $\begin{array}{l}\text { Nuclear reactors, boilers, machinery } \\
\text { and mechanical appliances }\end{array}$ & 0.87 & 14 \\
\hline $\begin{array}{c}\text { Wool, fine or coarse animal } \\
\text { hair; horsehair yarn and woven } \\
\text { fabric }\end{array}$ & 0.37 & 4.9 & Articles of iron or steel & 0.49 & 8 \\
\hline $\begin{array}{c}\text { Salt; sulfur; earths and stone; } \\
\text { plastering materials, lime and } \\
\text { cement }\end{array}$ & 0.21 & 2.8 & $\begin{array}{l}\text { Electrical machinery and equipment } \\
\text { and parts thereof; sound recorders } \\
\text { and reproducers, television image } \\
\text { and sound }\end{array}$ & 0.37 & 6 \\
\hline Meat and edible meat offal & 0.08 & 1.1 & Aircraft, spacecraft, and parts & 0.16 & 2.6 \\
\hline
\end{tabular}

[Table 5], referred from the data of IMF and Korea international trade association (KITA), summarizes the main exporting and importing countries of Mongolia, indicating that the share of China is exceptionally large[11]. China, the UK, Russia, Italy, and Singapore are the largest exporting countries of Mongolia. South Korea ranked 6th and 7th in 2018 and 2019, respectively. In particular, Mongolia has a high export dependency on China. In 2018, it exported 65 billion dollars' worth to China, which constituted approximately $93 \%$ of the Mongolian exports. Although it ranked second among the exporting countries, the UK is far behind China. Mongolia exported 173 million dollars to the UK and 86 million dollars to Russia. The shares of the UK and Russia were $2.5 \%$ and slightly over $1 \%$, respectively. Other countries' proportion of export volume was below 1\%. As of 2019, the proportion of Mongolia's exports to China has been over 90\%. Despite the slight change in the ranking, the five largest exporting countries have remained the same. Mongolia's main exporting items to China and the UK were minerals, such as copper and coal and coal and gold, respectively. China, Russia, Japan, South Korea, and the US are the largest importing countries of Mongolia. Although the dependency on China is not absolute, as in the case of exports, China still occupies a large share of the total imports. In 2018 and 2019, the proportions of Mongolia's imports from China were $30 \%$ and $36 \%$, respectively, which were the largest shares. As shown previously, import and 
export dependence on China is related to current Chinese investment. Since 2010, 30\% of the total investment money entering Mongolia has come from China. As a result, the trade structure and national GDP of Mongolia have made Chinese investment economically vulnerable. In 2019, the proportion of Mongolia's imports from Russia was $28 \%$. Meanwhile, the UK, Italy, and Singapore, which were some of the main exporting countries to Mongolia, are not included in the 10 largest importing countries. In particular, imports from Singapore were not large, despite the second-largest investment volume of Singapore, after China. The shares of imports from Japan, the US, and South Korea were $10 \%, 5 \%$, and 5\%, respectively. Mongolia is actively involved in import trade, mainly with China and Russia, as well as Japan, the US, and South Korea. Mongolia is importing electric energy, communication machines, and petroleum products from China and Russia. Mongolia imports automobile and related components from Japan and South Korea and freight truck and petroleumprocessed products from Japan and Korea, respectively. Japan and Mongolia have already signed the EPA, and its effects are visible at a certain level. Considering that Mongolia's importing items from South Korea and Japan are similar, the early conclusion of the EPA with Mongolia would be beneficial to Korea.

[Table 5] Main Export and Import Countries

\begin{tabular}{|c|c|c|c|c|c|}
\hline \multicolumn{6}{|c|}{ Export } \\
\hline \multicolumn{3}{|c|}{2018} & \multicolumn{3}{|c|}{2019} \\
\hline Ranking & Country & Volume (Million \$) & Ranking & Country & Volume (Million \$) \\
\hline 1 & China & 6,506 & 1 & China & 6,395 \\
\hline 2 & UK & 173 & 2 & UK & 274 \\
\hline 3 & Russia & 86 & 3 & Singapore & 148 \\
\hline 4 & Italia & 54 & 4 & Russia & 62 \\
\hline 5 & Singapore & 30 & 5 & Italia & 46 \\
\hline \multicolumn{6}{|c|}{ Import } \\
\hline \multicolumn{3}{|c|}{2018} & \multicolumn{3}{|c|}{2019} \\
\hline Ranking & Country & Volume (Million \$) & Ranking & Country & Volume (Million \$) \\
\hline 1 & China & 1,814 & 1 & China & 2,180 \\
\hline 2 & Russia & 1,464 & 2 & Russia & 1,713 \\
\hline 3 & Japan & 552 & 3 & Japan & 606 \\
\hline 4 & Korea & 308 & 4 & US & 292 \\
\hline 5 & US & 167 & 5 & South Korea & 291 \\
\hline
\end{tabular}

\subsection{Main Industry of Mongolia}

One characteristic of the Mongolian industry is that, on average, the employees are young, which can be positively evaluated in terms of work efficiency and job achievement. This section examines the industrial trends and characteristics of mining, which is Mongolia's backbone and the largest money-making industry. Mongolia is the 10th largest resource-rich country, possessing considerable mineral deposits and where the development of local mines and mineral exports are carried out through foreign investments. The trend of the mineral industry in the past four years is summarized in [Table 6], referred from data from Kotra[12].

[Table 6] Trading across Borders

\begin{tabular}{|c|c|c|c|c|}
\hline Year & 2016 & 2017 & 2018 & 2019 \\
\hline Mineral export (Billion \$) & 3.48 & 4.93 & 6.07 & 6.63 \\
\hline Share in Industry (\%) & 56 & 58 & 57 & 58 \\
\hline Share in GDP(\%) & 21 & 24 & 24 & 25 \\
\hline
\end{tabular}


In the early 2000s, the agriculture and stockbreeding industry occupied a large proportion of the national GDP of Mongolia, which was originally a country of nomads. Following the constant inflow of foreign capital for mine development and government-led developmental policies, the mining industry has become a new key industry that supports the national finance. It constitutes approximately $25 \%$ of Mongolian GDP and its share of total industry is approximately $60 \%$. The share of the mining industry in the GDP was $21 \%$ in 2016 and increased to $25 \%$ in 2019. At the same time, the amount of mineral exports, which was less than 3.5 billion USD in 2016, nearly doubled in 2019 to record 6.6 billion USD. Mongolia possesses over 80 types of minerals, and its copper and fluorite deposits rank second and third, respectively, worldwide. In addition, Mongolia ranks fourth and ninth in terms of its coal and molybdenum deposits, respectively. It also possesses more than $15 \%$ of the total number of rare-earth elements, which is globally a strategic mineral (National Statistics Office of Mongolia). Mongolia is also rich in iron, gold, silver, zinc, and uranium deposits. The rich mineral deposits are a strong advantage to the Mongolian economy, which acts as a foundation for consistently maintaining high economic growth. However, the national economy can be highly vulnerable to changes in the global market price of minerals if the economic structure entirely depends on the mineral industry, and other local industries are in stagnant condition. The Mongolian government enacted a new Mining Act in 2006, which designated major mines as strategic mines and allowed the government to possess a certain stake so that it could have some controlling power over foreign investment capital. A positive effect on the Mongolian economy is anticipated in the long term if foreign capital is also used in establishing transportation infrastructure in underdeveloped regions of Mongolia, instead of solely developing mines.

Although the proportion of the whole industry has largely decreased recently, the agricultural and stockbreeding industry was the main leader of Mongolian economic growth. It constituted more than one-fourth (27\%) of the national GDP in the past. The proportion decreased to one-tenth in 2019. Within the agricultural and stock breeding industry, stock farming occupied the majority, and the industry focused on breeding cattle, sheep, goats, and horses. Meanwhile, the agricultural products produced in Mongolia are mostly consumed in local markets. Besides these, wool, cashmere, leather, and meat are also exported. Meat is exported to China, Russia, Kazakhstan, and Iran, and wool, cashmere, and leather are exported to China, the UK, Italy, South Korea, India, and Germany.

Despite its broad territory, the infrastructure environment of transportation, including railways and roads, and its distribution are poor in Mongolia. The Mongolian government is continuously promoting infrastructure construction projects, including roads, housing, and transportation, as a means of economic stimulus. In Mongolia, the construction industry maintained a very high growth rate for several years before the global economy experienced a downturn in 2020, with a proportion of over $4 \%$ out of the national GDP. The demand for construction materials increased. Most construction materials required in Mongolia have been imported from China and Russia. However, as the local production of some of these, such as cement and concrete, has recently increased, dependence on imports has decreased. In contrast, imports of other construction materials, including glass, rebar, plastic tubing, and synthetic wood, are still growing. Hence, the construction cycle is expected to recover after a certain adjustment period in the future.

Due to the absence of a local pharmaceutical company, Mongolia imports most pharmaceuticals. In particular, the preference for and proportion of Korean pharmaceuticals in Mongolia are currently increasing, and Korea is the third or fourth largest pharmaceutical importing country of Mongolia. The import volume of pharmaceuticals in Mongolia, which is less than 0.1 billion USD as of now, is expected to grow in the long term. In addition, the Mongolian beauty industry is rapidly growing. In addition to local economic growth, the growth in the import volume is attributed to the fact that young women, who are the main consumers of the beauty industry, are taking increased interest in cosmetics. Mongolia imports beauty products from Japan, France, and South Korea, and demand is expected to 
grow further.

\section{Trade environment and relationship between South Korea and Mongolia}

The cooperation and trade between Korea and Mongolia presented in this chapter are based on [Table 7], referred from the macroeconomic data presented by the KITA and the Korea Customs Service (KCS), which manages and supervises import and export customs clearance. An analysis was conducted using these data. The year 2021 marked the 31st anniversary of the establishment of diplomatic ties between South Korea and Mongolia. The trade volume between the two countries has recently reached 300 million USD[13]. Despite the considerable growth in trade volume from the past, the volume has been rather stagnant since 2018. The growth of this trade volume is attributed to the increased purchasing power of individuals and companies following the economic growth of Mongolia.

[Table 7] Trade Status between Korea and Mongolia

\begin{tabular}{|c|c|c|c|c|c|}
\hline Division & \multicolumn{2}{|c|}{ Export (Million \$) } & \multicolumn{2}{c|}{ Import (Million \$) } & \multirow{2}{*}{$\begin{array}{c}\text { Trade balance } \\
\text { (Million \$) }\end{array}$} \\
\hline Year & Volume & Case & Volume & Case & 250 \\
\hline 2020 & 271 & 22,510 & 21 & 11,561 & 258 \\
\hline 2019 & 291 & 25,463 & 33 & 7,481 & 281 \\
\hline 2018 & 308 & 23,263 & 27 & 6,923 & 214 \\
\hline 2017 & 228 & 18,355 & 14 & 5,203 & 199 \\
\hline 2016 & 209 & 15,385 & 10 & 5,539 & \\
\hline
\end{tabular}

During the past five years, South Korea has recorded constant trade surplus with Mongolia. In 2016, Korea exported 209 million USD to Mongolia and imported 10 million USD from Mongolia, recording a large surplus of 200 million USD. Between 2017 and 2018, the exports increased by 35\% to 308 million USD and the imports increased by $93 \%$ to 27 million USD, creating a trade surplus of 281 million USD. In 2019 and 2020, exports slightly decreased from those in 2018, but South Korea still achieved 250 million USD surplus as imports also decreased. Mongolia is in constant trade deficit with South Korea, and the deficit amount is growing. Mongolia does not occupy a large share of the total trade of Korea. However, as the country can become a major supply and consumption market for South Korea depending on its economic growth and potential, it is now necessary to develop appropriate policies. To expand the collaborative relation between South Korea and Mongolia in a more positive and multilayered manner, diversification of trading items, which can reduce the deficit of Mongolia to a certain level, will be necessary, together with an expansion of investment in Mongolia and policy supports.

The following is a study of the main items imported and exported between South Korea and Mongolia. According to [Table 8], referred from KITA and KCS data, the main export items for South Korea included tobacco, freight trucks, petroleum and bitumen, beauty products and cosmetics, and heavy machinery for mining and construction.

[Table 8] Main Export and Import Items based on South Korea

\begin{tabular}{|c|c|c|c|c|}
\hline \multirow{2}{*}{ Ranking } & \multirow{2}{*}{ HS code } & \multirow{2}{*}{ Export Items } & \multicolumn{2}{|c|}{ Volume (Million \$) } \\
\cline { 3 - 5 } & & & 2019 & 2020 \\
\hline 1 & 2402 & Tobacco and Cigarettes & 21 & 28 \\
2 & 8704 & Motor vehicles for the transport of goods, incl & 23 & 18 \\
\hline 3 & 2710 & Petroleum oil and oils obtained bituminous minerals & 24 & 12 \\
\hline 4 & 3304 & Beauty or make-up preparations & 12 & 12 \\
\hline
\end{tabular}




\begin{tabular}{|c|c|c|c|c|}
\hline 5 & 8429 & Bulldozers, angledozers, graders & 15 & 11 \\
\hline \multirow{2}{*}{ Ranking } & \multirow{2}{*}{ HS code } & Import Items & \multicolumn{2}{c|}{ Volume (Million \$) } \\
\cline { 3 - 5 } & 2613 & Molybdenum ores and concentrates. & 12 & 2019 \\
\hline 1 & 6110 & Pullovers, Jerseys, cardigans, waistcoats and similar articles, knitted & 10 & 5 \\
\hline 2 & 5102 & Fine or coarse animal hair, not carded or Combed. & 0 & 2 \\
\hline 3 & 2529 & Feldspar; leucite; nepheline and nepheline syenite; fluorspar. & 3 & 1 \\
\hline 4 & 6214 & Shawls, scarves, mufflers, mantillas, veils and the like. & 0 & 1 \\
\hline 5 & &
\end{tabular}

Until October 2020, exports of tobacco and cigarettes increased from the last year and its proportion out of total export reached $10 \%$. Exports of freight trucks slightly decreased, with a 7\% share of total export. The proportions of petroleum and bitumen, beauty products, and heavy machinery for mining and construction were mostly around $4 \%$. Among them, the amount of petroleum and bitumen export dropped by $50 \%$ from the last year. This was because the demand diminished due to the economic slowdown following the COVID-19 outbreak. South Korea mainly imported mineral resources from Mongolia, including the metal of molybdenum and nonmetals of feldspar, knitted goods and wool of coarse animal hair, and livestock and components, which coincided with the main export items of Mongolia. In 2020, the proportions of most import items decreased from the last year, except for wool, which increased slightly. However, as the proportion of related imports was very small, the impact was not significant. The trade imbalance is expected to diminish to a certain level, according to the conclusion of the EPA between Korea and Mongolia.

Mongolia is consistently promoting economic exchange and trade with third-party nations to reduce economic and energy dependence on China and Russia. In this situation, Mongolia concluded the EPA with Japan in 2015 for the first time[14]. The Mongolia-Japan EPA, which came into effect from June 2016, has main contents that declare duty exemption of approximately 5,700 items, among which tariffs of approximately 2,000 items are agreed to be lifted phase-by-phase from a minimum of four years to maximum 20 years. South Korea agreed to sign an economic treaty with Mongolia in 2016 and is making consistent efforts to finalize the deal[15]. Mongolia also agreed to conclude economic treaties with China and Russia in the foreseeable future in 2017 and 2018, respectively.

[Table 9] Trade Status between Japan and Mongolia

\begin{tabular}{|c|c|c|c|}
\hline Year & Export (Million \$) & Import (Million \$) & Trade balance (Million \$) \\
\hline 2020 & 23 & 388 & -365 \\
\hline 2019 & 15 & 606 & -591 \\
\hline 2018 & 37 & 552 & -515 \\
\hline 2017 & 15 & 363 & -348 \\
\hline 2016 & 14 & 331 & -317 \\
\hline
\end{tabular}

According to [Table 9], referred from the Kotra and KITA data, the average annual trade between Japan and Mongolia from 2016 to 2017 was 362 million USD. After the treaty came into effect, the

trade nearly doubled to an average of 605 million USD in 2018 and 2019. Similarly, if the EPA between South Korea and Mongolia is successfully achieved, the trade volume between the two countries will grow considerably. Mongolia imports most of the consumer goods for domestic use from foreign countries due to insufficient manufacturing facilities for consumer goods production. Meanwhile, Korea is promoting trade expansion and collaboration reinforcement within the Northeast Asian region. The treaty is expected to create positive effects for both countries. As mentioned earlier, the trade between the two countries is currently under a stagnant condition. Although this might be largely because of COVID-19, increased trade expenses due to poor transportation and traffic networks in Mongolia and the Mongolian government's policies aimed at protecting local industries 
are also to be blamed.

Hence, processing the EPA conclusion as quickly as possible will be beneficial. Considering the complementariness of the trade items of the two countries, Mongolian imports of trucks and related components, together with consumer goods, are expected to grow by large after the treaty conclusion. Meanwhile, South Korea will further expand its investment and mineral resource development in Mongolia. Mongolia became a member country of the Asia-Pacific Trade Agreement (APTA) in 2020. APTA is an intra-regional trade treaty founded in 1975, led by the five countries of India, South Korea, Laos, Sri Lanka, and Bangladesh, pursuing tariff reduction and trade benefit expansion among the member countries. In 2011, China joined the APTA, and Mongolia became the seventh member.

\section{Discussion}

\subsection{Analysis Method}

This study conducted a SWOT analysis devised by comprehensively utilizing the macroscopic data and analysis results presented in the previous chapters. The related method is an analysis method that analyzes the internal and external environments of the research subject to define strengths, weaknesses, opportunities, and threat factors and seeks solutions based on these factors. To find and suggest plans for expanding trade and cooperation between South Korea and Mongolia, this study examined various strengths and weaknesses that affect the Mongolian economy and industry from an internal perspective and investigated opportunities and threats factor in detail from an external perspective.

[Table 10] SWOT for Mongolia

\begin{tabular}{|c|c|c|c|}
\hline \multicolumn{4}{|c|}{ Division and Contents } \\
\hline Strengths & $\begin{array}{l}\text {-Abundant mineral reserves } \\
\text { and continued development } \\
\text {-Expansion of young consumers } \\
\text {-geographical advantage }\end{array}$ & Opportunities & $\begin{array}{l}\text {-Expansion of government's industrial } \\
\text { policy and economic agreement } \\
\text {-Increase in overseas investment } \\
\text {-Expansion of the online trading market } \\
\text { and influence of Hallyu-wave }\end{array}$ \\
\hline Weakness & $\begin{array}{l}\text {-Competing with Chinese companies } \\
\text { in the local market } \\
\text {-High corruption rate and low } \\
\text { market openness } \\
\text {-Small market size }\end{array}$ & Threats & $\begin{array}{l}\text {-Expansion of interest repayment } \\
\text { by investment } \\
\text {-Expansion of protective tariffs to } \\
\text { foster domestic industries } \\
\text {-Falling mineral prices worldwide }\end{array}$ \\
\hline
\end{tabular}

\subsection{Main Discussions}

The following are some of the main points of discussion. One of the biggest strengths of Mongolia is its resource-richness with a possession of large deposits of multiple minerals. The mineral resources have been the major driving force for the country's constantly high economic growth recently. Mongolia also has geographic advantage. South Korea is currently promoting the New Northbound Policy, which aims at expanding the economic zone that connects to the Eurasian Continent. With its geopolitical location between China and Russia, Mongolia can become a logistics and distribution hub in the future[16]. In addition, Mongolia has relatively young population. The young generation is familiar with the Korean culture, which is gaining worldwide popularity these days, and exhibits favorable attitude toward it. It can act as a strength in cooperation with Korean companies or in the recruitment of the production workforce. There are several weaknesses of the Mongolian economy, among which the previously mentioned high economic dependency on China is the largest. Chinese companies frequently enter the Mongolian market and are actively involved in FDI. Hence, the 
competition between Korean and Chinese companies in the local market is inevitable, creating vulnerable points for Korean enterprises. Recently, the Mongolian government has been developing new policies as a means of reducing the China-centered economic structure and reinforcing collaboration with other countries. In addition, it has taken a favorable position on economic agreements with economic powers, including Korea, which can be a good strategic choice for Korea as well[17]. However, Mongolia lags behind other countries within the area in terms of the customs clearance procedure and openness of the economy. Mongolia has a substantially high CPI[18]. Corruption is a common problem that many emerging Asian countries experience. The possibility that the resolution of problems surrounding business entry into the local market and authorization can be controlled by the personal connection to the stakeholders in Mongolia is certainly a weakness. Currently, Mongolia is tackling corruption at a government level. It has a total population of approximately 3.3 million and a small domestic market size. However, the potential as a logistics supply base is large, considering its extensive territory and rich mineral resources. Next, this study examined the Mongolian economy from an external viewpoint to identify opportunities and threat factors. Recently, online transactions have been increasing in the Mongolian market, and the popularity of Korean cosmetics has been high due to the influence of the Hallyu wave[19]. In addition, investments from overseas according to development potential are continuously maintained. Government-led projects of fostering the manufacturing industry and infrastructure construction are in consistent progress[20][21]. Hence, Korean companies equipped with strong competitiveness in the relevant field can welcome this opportunity. Meanwhile, due to the global economic slowdown, the price of mineral resources is decreasing, and interest payment to foreign investment money, which previously flew in for developing mines, is increasing. This is a risk factor that can drive the economic growth of Mongolia. The Mongolian government is creating and reinforcing various protective tariffs aimed at protecting the domestic industry to reduce the side-effects originating from foreign companies' rigorous investment and capital inflow, which poses another risk factor.

\section{Conclusions and Implications}

This study closely examined the diverse factors that influence the Mongolian economy and industry from both internal and external perspectives. The paper proposes plans for expanding cooperation and trade between South Korea and Mongolia from both countries' perspectives. First, the Korean government should pay close attention to the infrastructure building policies that the Mongolian government is currently promoting and provide diverse information and financial support to Korean construction firms so that they can develop an interest in the Mongolian market and enter the market more easily. Although Mongolia has a small domestic market, the construction of infrastructure such as railways, housing, and communications is in constant demand because of the rapid economic growth and extensive territory. Awareness regarding Korean products is growing in the Mongolian market owing to the increasing popularity of Korean culture in the entire Asian region. This is the perfect time for Korean companies of beauty products and cosmetics, including medical supplies and electronic devices, to raise their market share in Mongolia. Specifically, participation in mine development and the energy industry, where competition with foreign countries is fierce, should be promoted, centering on large companies. Small- and medium-sized companies need to focus on consumer goods industries that have less fierce competition and weak local manufacturing base. Examining the population of Mongolia, young consumers with a strong desire for education occupy a large proportion, and these human resources can be aptly used when building a production base. While observing the growth of the online market, which mainly targets young consumers, Korean companies can develop consumer products aimed at young people or collaborate with local companies to dominate the distribution market in advance. Because Mongolia is a globally mineral-rich country, 
foreign investment aimed at developing and monopolizing resources consistently flows in. Thus, machines and components required for developing mines and building transportation networks are in constant demand. Hence, efforts should be made to boost demand for Korean products through the active marketing of mining and construction machine tools required for mine development and infrastructure construction. Because Mongolia is a landlocked country that is geopolitically close to China and Russia and is a newly emerging country, expenses for recruiting a workforce and building industrial infrastructure are relatively lower than those incurred by other countries. Hence, ways to use these cost advantages to turn the country into an intra-regional logistics bridgehead need to be sought. Agricultural technology in South Korea is being advanced and enhanced. However, the country does not have sufficient farmland to apply this technology, and labor and management expenses are very high. South Korea should develop a plan for collaborating Mongolia, which possesses extensive territory and increasing demand for producing agricultural products that have high added values, as a new entry and production base for farming.

This paper proposes several directions from the viewpoint of Mongolia. The fact that the economic policies currently in progress can be continued stably for a foreseeable future because of the victory of the ruling party of Mongolian People's Party in the general elections in 2020 is positive news. Furthermore, the Mongolian government has recently made purification efforts to reduce CPI, which promises a good opportunity for foreign enterprises to enter the local market. With a higher level of democracy than China and Russia, government-to-government cooperation with Mongolia is relatively easier. Thus, there is a need for South Korea and Mongolia to sign the Korea-Mongolia EPA without delay, which they have already debated profoundly. The joint research for treaty conclusions needs to be more promptly and profoundly progressed, seeking early resolution through continued consultation with relevant experts. If Mongolia has lower economic growth or competitiveness than its partner country, the treaties, which are promoted by the Mongolian government as a means of changing the existing China-centered economic structure and finding a new springboard, might make Mongolia a mere supply base of raw materials with high dependence on the partner. However, the previously mentioned concerns can be effectively resolved if Mongolia uses the treaties as an opportunity to invite financial and technological support from the partner country to establish local infrastructure and expand the domestic manufacturing base. Mongolia should create and develop more open industrial policies. Although the country is more open compared to the past, the speed of change is still slow. As an emerging country, continued growth cannot be achieved when too much focus is placed on the protection of domestic industry. In particular, Mongolia should closely observe the useful economic system and promising industries of the treaty partner country to derive appropriate parts for the country and modelize and localize them to create a beneficial opportunity and advantage that can contribute to national economic growth. This paper proposes plans for expanding cooperation and trade between South Korea and Mongolia based on an analysis from both countries' economic, trade, and industrial perspectives. From the Korean perspective, the fields of entry and types of companies are mentioned. They should enter the mining and energy business and the consumer goods industry, respectively, which are appropriate to the size of the company, and suggest ways to secure production bases and cooperate with local companies. From the Mongolian perspective, it is suggested to quickly conclude an economic freedom agreement with Korea, relax protection policies, and utilize the advantages of advanced partner countries appropriately for their own country. The research method largely depends on qualitative methods for the evaluation, and the description in this study has a limitation of suggesting proposals based on quantitative methods, such as SWOT analysis. The researchers plan to continue studying how trade between South Korea and Mongolia will change after the actual EPA is signed. In this case, it will mainly use quantitative statistics and evaluations. 


\section{References}

[1] Odmunkh Odmaa, Soo-Joong Nam, A Study on Characteristics and Implications of Mongolia's Trade Structure with China and Korea, The Journal of Asian Studies, (2020),Vol.23, No.1, pp.89-124. DOI: 10.21740/jas.2020.02.23.1.89

[2] Jong Soo Han, Won Ick Choi, International Trade Pattern between Korea and Mongolia and Policy Alternatives for Economic Cooperation, The Journal of Peace Studies, (2015), Vol.16, No.5, pp.127-149.

[3] Ji-Won Park, External dependence of Mongolian economy and cooperation strategy of Korea, The Asia-Pacific Research Center, (2012),Vol.36, No.3, pp.317-348. DOI : 10.21196/aprc.36.3.201211.010

[4] Jung-Sub Park, Jae-Eun Lee, A Study on Strategies for Korean Logistics Enterprises to Enter Mongolia, Korea Logistics Review, (2014), Vol.24, No.2, pp.239-267. UCI : G704-001067.2014.24.2.008

[5] Dong-Young Jeong, Mongolian Election Results and Future Prospects, EMERiCs, (2021)

[6] https://comtrade.un.org/, UN Comtrade, June 29 (2021)

[7] Ji-Hyun Yoon, Mongolia, Implementation of the IMF bailout program, Korea Institute for International Economic Policy, (2017), No.121, pp.1-3.

[8] https://www.transparency.org/en/cpi/2020/index/nzl, TI, Jul 1 (2021)

[9] https://www.doingbusiness.org/en/rankings, Doing business, Jul 1 (2021)

[10] https://wits.worldbank.org/countrysnapshot, World bank, Jul 1 (2021)

[11] https://www.kita.net/, KITA, May 25 (2021)

[12] Mongolia Progress Report, Kotra (2020)

[13] https://www.customs.go.kr/, Jul 1 (2021)

[14] Jong-Won Lee, Countermeasures Developed by Korea Following the EPA between Japan and Mongolia, The Journal of International Trade \& Commerce, (2017), Vol.13, No.2, pp.459-472.

[15] The Promotion of Korea-Mong EPA and the Expansion of Trade between Korea and Mongolia, Korea Institute for International Economic Policy, (2020)

[16] Song-Min Geun, The Characteristics of South Korea's New Northern Policy and Cooperation with Eurasia Countries' Initiatives Focused on China, Mongolia and Russia, Journal of Digital Convergence, (2019), Vol.17, No.7, pp.1-13. DOI: 10.14400/JDC.2019.17.7.001

[17] Taeh-Wang Kim, Crafting Economic Cooperation Strategies to Promote Trade and Investment between Korea and Mongolia, The Journal of International Trade \& Commerce, (2015), Vol.11, No.2, pp.231-244.

[18] Munkhuu Gangtulga, Langhae Yang, Moon-Ho Song, Improvements to Prevent Bribery Crime and Corruption in Mongolia, The Institute for Northeast Asian Law Chonbuk National University, (2017), Vol.11, No.2, pp.79-100.

[19] Gandulam Ganbold, Hyeong-Yu Jang, The Effects of Mongolian Consumer's Korean Cosmetics Selection Attributes on Brand Reliability and Purchasing Intention: -Moderating Effect of Advertising Media and Promotion Type-, The Journal of the Korea Contents Association, (2020), Vol.20, No.10, pp.134-145. DOI: 10.5392/JKCA.2020.20.10.134

[20] Tseg Narantse, Hyun-Hee Park, The Impact of FDI on Economic Growth in Mongolia and Central Asia, International Commerce and Information Review, (2017), Vol.19, No.2, pp.65-84.

[21] Jung-Hoo Park, Mongolian Foreign Policy Determinants and Challenges, THE JOURNAL OF POLITICAL SCIENCE \& COMMUNICATION, (2021), Vol.24, No.2, pp.89-118. DOI: 10.15617/psc.2021.6.30.2.89 